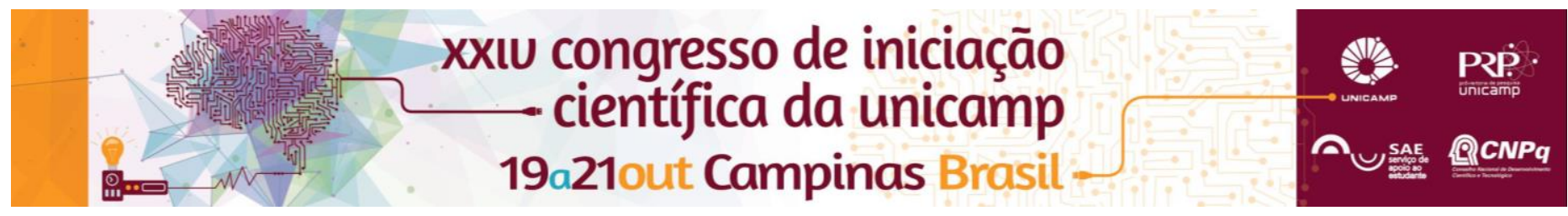

\title{
Petrographic and geochemical signatures of the main rock types of Atibaia (SP) and Jaguari (SP/MG) rivers sub-basins
}

\author{
Luiza de C. Mendes*, Bruno C. Mortatti, Jacinta Enzweiler
}

\begin{abstract}
Watersheds are dynamic systems, marked by constant interaction of river waters with groundwaters and other environmental compartments (atmosphere, biosphere, lithosphere, and pedosphere). The composition of natural waters results from these interactions, but that of rocks dominates. Among the trace constituents of surface waters, the concentrations of rare earth elements (REE) depend on chemical weathering of the rocks and, secondarily, on hydrogeochemical processes and reactions. The results of this study of mineralogy and geochemistry of the main rock types found in the sub-basins of the Atibaia (SP) and Jaguari (SP/MG) rivers will help to understand hydrogeochemical processes in these watercourses. The rocks found and sampled in the study area are, mostly, granitoids but some samples show metamorphism. The mineral composition of these rocks includes accessories such as allanite, rutile, garnet, zircon and apatite. The rock chondrite REE normalized patterns show enrichment in light REEs and depletion in heavy REEs, which is in agreement with the mineralogical composition of the samples.
\end{abstract}

\section{Key words:}

Petrography, Lithogeochemistry, Rare Earth Elements (REE)

\section{Introduction}

Hydrological, hydrogeological and climatic factors of the drainage basin control the chemical composition of surface waters, but the source of most dissolved ions are the rocks (Faure $\left.{ }^{1}, 1998 ; \mathrm{Hem}^{2}, 1985\right)$.

The aim of this study was to review the geological context of the sub-basins of Atibaia (SP) and Jaguari (SP/MG) rivers, collect and characterize representative rock samples, to obtain their primary petrographic and geochemical features. The data will help to understand the hydrogeochemistry of the surface waters of the area.

\section{Results and Discussion}

The paragenesis of the studied rocks presents mainly quartz, K-feldspar, plagioclase, and biotite. The identified accessory phases, in decreasing frequency, were zircon, garnet, apatite, allanite and rutile (Figure 1). Most samples are granitoids classified as granodiorites, diorites, syenites, monzonites and monzodiorites. Some samples present metamorphic features, such as gneissic banding and migmatized portions.

The granitoids of the study area pertain to the Bragança Paulista, Nazaré Paulista, and Atibaia magmatic suites, besides Piracaia, Varginha, Terra Boa, Pedra Branca and Serra do Barro Branco complexes. The last three belong to the São Roque domain and former to the Socorro-Guaxupé domain.

Some samples of the Socorro-Guaxupé (Piracaia complex) and São Roque (Serra do Itaberaba) domains are metasedimentary rocks such as graphite-muscovite quartzite and muscovite quartzite, respectively.
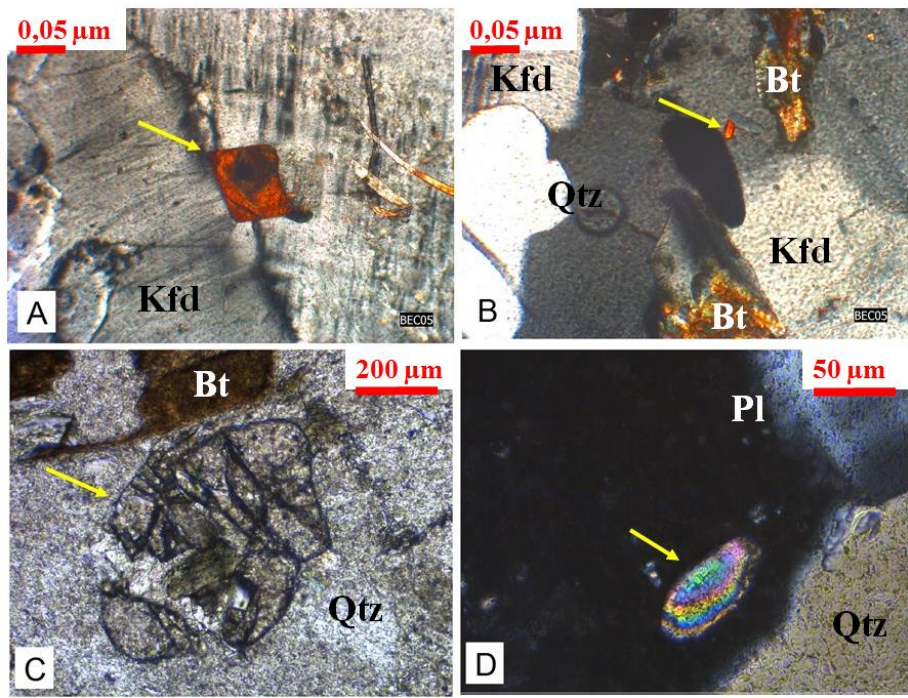

Figure 1. Photomicrographs of accessory minerals (indicated by yellow arrows) identified in thin sections: A) Allanite, B) Rutile, C) Garnet and D) Zircon.

The geochemical data for analyzed samples indicate that the rock composition of the study area is predominantly sub-alkaline. The chondrite-normalized REE patterns show enrichment of light over heavy REE (La/Yb normalized ratios between 11 and 183), as well as negative Eu anomalies $\left(\mathrm{Eu} / \mathrm{Eu}^{*}=0.35\right.$ to 0.90$)$ in most samples.

\section{Conclusions}

The most frequent lithotype in the sub-basins area consists of sub-alkaline composed granitoids, enriched in light REEs and with negative Eu anomalies.

${ }^{1}$ FAURE, G. Principles and Applications of Geochemistry. Prentice Hall. Upper Saddle River, New Jersey, USA, 2 ed, p. 600, 1998.

${ }^{2}$ HEM, J. D. Study and Interpretation of the Chemical Characteristics of Natural Water. Geological Survey Water Suplly Paper. Alexandria, Virginia, USA, p. 272, 1985. 